\title{
Toxic effects of neem seed cake on the larval-pupal (prepupal) stage of Mediterranean fruit fly (Diptera: Tephritidae)
}

\author{
Márcio A. Silva ${ }^{1 *}$, Clarice D. Alvarenga ${ }^{2}$, Gerane C.D. Bezerra-Silva ${ }^{1}$, Thiago Mastrangelo ${ }^{3}$, Gleidyane N. Lopes-Mielezrski ${ }^{1}$, \\ Terezinha GIUSTOLIN ${ }^{2}$
}

\author{
${ }^{1}$ Dep. Entomol. Acarol., Esc. \\ Sup. Agric. Luiz de Queiroz, \\ Univ. São Paulo, CP 9, \\ 13418-900, Piracicaba, SP, \\ Brazil \\ silvamarcioalves@gmail.com \\ 2 Dep. Ciênc. Agrár., Univ. \\ Estadual Montes Claros, CP \\ 91, 39440-000, Janaúba, MG, \\ Brazil \\ ${ }^{3}$ Cent. Energ. Nucl. Agric., \\ Univ. São Paulo, CP 96, \\ 13400-970, Piracicaba, SP, \\ Brazil
}

${ }^{*}$ Correspondence and reprints

Received 25 October 2010 Accepted 12 January 2011

Fruits, 2011, vol. 66, p. 363-369 (C) 2011 Cirad/EDP Sciences All rights reserved DOI: 10.1051/fruits/2011050 www.fruits-journal.org

RESUMEN ESPAÑOL, p. 369
Toxic effects of neem seed cake on the larval-pupal (prepupal) stage of Mediterranean fruit fly (Diptera: Tephritidae).

Abstract - Introduction. Traditionally the control of fruit flies is based on the use of pesticides, which increase production costs and have led to many environmental concerns. Our study aimed to evaluate the effect of neem cake on the larval and pupal stages of Ceratitis capitata. Materials and methods. Third instar larvae were transferred to plastic vials with neem cake in different proportions. The treatments consisted of vermiculite with neem cake in the concentrations: control (vermiculite only), then (10, 25 , 50,75 and 100)\% of neem seed cake. The bioassay was completely randomized, with six treatments, ten replicates and ten third instar larvae per replicate. The results were statistically analyzed. Results. At concentrations of $75 \%$ or more of neem cake in vermiculite, practically no adult flies emerged. At 50\%, more than $80 \%$ of the adults did not emerge and the pupal period was prolonged. The sex ratio of the adults was not affected after the contact of the pupae with the neem cake. The estimated lethal concentrations to kill $50 \%$ and $90 \%$ of the population were $30.6 \%$ and $51.6 \%$, respectively. Conclusion. The neem seed cake has contact actions against the larval-pupal stage of $C$. capitata. Neem seed cake in the pupation substrate can cause high mortality when its concentration is $50 \%$ or more, and it prolongs the delay of the pupal period of C. capitata.

Brazil / Azadiracbta indica / Ceratitis capitata / Tephritidae / insect control / botanical pesticides / biological control

\section{Effet toxique du tourteau de graines de neem sur le stade prépupe de la mouche des fruits méditerranéenne (Diptera: Tephritidae).}

Résumé - Introduction. Traditionnellement, le contrôle de la mouche des fruits est basé sur l'utilisation de pesticides, ce qui augmente les coûts de production et conduit à de nombreux problèmes environnementaux. Notre étude a cherché à évaluer l'effet du tourteau de neem sur les stades larvaires et nymphaux de Ceratitis capitata. Matériel et méthodes. Des larves de troisième stade ont été transférées dans des flacons en plastique contenant de la vermiculite mélangée à du tourteau de graines de neem à différentes concentrations : le traitement témoin a été constitué de vermiculite seule ; cinq autres traitements ont été appliqués à partir de (10, 25, 50, 75 ou 100) \% de tourteau de graines de neem ajoutés à de la vermiculite. Un bio-essai a été effectué selon un dispositif totalement aléatoire, avec six traitements, dix répétitions et dix larves par répétition. Les résultats ont été statistiquement analysés. Résultats. Dans les milieux contenant de la vermiculite à $75 \%$ ou plus de tourteau de neem, pratiquement aucune mouche adulte n'a émergé. Dans les milieux à $50 \%$, plus de $80 \%$ des adultes n'ont pas émergé et, pour ceux qui ont émergé, la période nymphale a été prolongée. La sex-ratio des adultes n'a pas été affectée après contact des chrysalides avec le tourteau de neem. Les concentrations mortelles de tourteau dans le substrat de pupaison estimées pour tuer $50 \%$ et $90 \%$ de la population de mouches ont été respectivement de 30,6\% et 51,6\%. Conclusion. Le tourteau de graines de neem agit par contact sur le stade prépupe de C. capitata. Ce tourteau mélangé au substrat de nymphose peut provoquer une mortalité élevée à partir d'une concentration de $50 \%$; il allonge la période nymphale de C. capitata.

Brésil / Azadirachta indica / Ceratitis capitata / Tephritidae / lutte anti-insecte / pesticide d'origine végétale / lutte biologique 


\section{Introduction}

Currently, the non-tariff barriers of the international market under the flag of phytosanitary patrimony security are one of the strategies of globalization and, in this context, fruit fly control (Diptera: Tephritidade) has become a primary step in the conquest of new markets. Ceratitis capitata (Wied.), the Mediterranean fruit fly (medfly), is considered the most harmful spreader and invader among all Tephritidae [1]. The females of this species lay their eggs in fruits, and larvae develop eating their pulps. The larvae, when fully developed, leave the fruit and enter the soil to become pupae, from which the adults later emerge, starting a new cycle again [2].

Traditionally, medfly control is done by toxic bait sprays, based on an attractant and food stimulant and an insecticide, aiming to control the adults. The search for alternatives for agrotoxic products for the integrated management of Tephritidae is not new in the scientific environment because, beyond the related environmental and human health problems, the societies of both developed and developing countries demand fruits without the presence of fruit flies, and specially pesticide residues.

Recently, some studies with extracts or oil from the neem seed, Azadirachta indica A. Juss. (Rutales: Meliaceae), have revealed physiological and behavioral effects on fruit flies. The derivates from neem caused repellence or oviposition deterrence in studies with Bactrocera dorsalis (Hendel) in guava [3, 4], Bactrocera cucurbitae (Coquillett) in pumpkin [4] and Anastrepha ludens (Loew) in oranges [5]. The same derivates had effects on the biology of some Tephritidae species: metamorphosis [6-8], fecundity [6, 9, 10], longevity [6] and flight ability [11].

Among several classes of compounds with insecticidal potential found in plants of the Rutales order, to which neem belongs, limonoids deserve special attention. Among the limonoids that have already been identified from the neem tree, azadirachtin, a limonoid with a C-dry ring, is the most investigated and considered the one with most potential for the integrated pest management of insects.
The azadirachtin molecule is very complex [12]. Its full synthesis was accomplished with 71 steps, with a yield of $0.00015 \%$ [13, 14]. Currently, all products based on neem available in the world market are prepared from compounds extracted from the plant. These products can be used as powders, aqueous or organic extracts, oils (fixed or essences), and cake. After pressing the seeds, it is possible to obtain $47 \%$ of oil [15], along with $10 \%$ of the total seed azadirachtin; $90 \%$ of the azadirachtin remains in the neem cake (solid wastes of pressed seed) [16].

Despite the higher concentration of azadirachtin in the seed cake, there are few studies with this by-product for pest control. Moreover, there are applications for phytopathogenic fungi control [17] and mainly for phytonematodes [18].

The technological approaches for management available usually aim at the control of the adult insects and little attention is given to the pupal stage, when the insect does not move in the soil and, consequently, becomes very vulnerable to control measures. Investigations into the effects of neem cake on that stage are necessary before the adoption of alternative measures for the integrated management of fruit flies. Therefore, our study aimed to evaluate neem cake effects on the larval-pupal (prepupal) stage of C. capitata.

\section{Materials and methods}

\subsection{Experiment}

The experiment was conducted under controlled conditions of temperature [(25 \pm 1) $\left.{ }^{\circ} \mathrm{C}\right]$, relative humidity $[(60 \pm 5) \%]$ and photophase $(14 \mathrm{~h})$. To obtain the third instar larvae (prepupae), eggs from a cage with 8day-old C. capitata were collected (to observe the rearing procedures, see [19]). Then, the eggs were transferred to a plastic vial with an artificial diet for the larval rearing. After 8 days, the third instar larvae (prepupae) were put into smaller vials with the respective treatments.

The neem cake (dry and ground residue of seeds, obtained after the oil extraction) 
was added and mixed with the vermiculite (substrate for pupation) in different proportions. To define the treatments, an acrylic vial with known volume $\left(42.39 \mathrm{~cm}^{3}\right)$ was used as a reference to establish the treatments:

- treatment 1. Control: 100\% of the acrylic vial volume with vermiculite $\left(42.39 \mathrm{~cm}^{3}\right)$.

- treatment 2: $90 \%$ of vermiculite $\left(38.15 \mathrm{~cm}^{3}\right)$ and $10 \%$ of neem cake $\left(4.24 \mathrm{~cm}^{3}\right)$.

- treatment 3: $75 \%$ of vermiculite $\left(31.79 \mathrm{~cm}^{3}\right)$ and $25 \%$ of neem cake $\left(10.60 \mathrm{~cm}^{3}\right)$.

- treatment 4: $50 \%$ of vermiculite $\left(21.195 \mathrm{~cm}^{3}\right)$ and $50 \%$ of neem cake $\left(21.195 \mathrm{~cm}^{3}\right)$.

- treatment 5: 25\% of vermiculite $\left(10.60 \mathrm{~cm}^{3}\right)$ and $75 \%$ of neem cake $\left(31.79 \mathrm{~cm}^{3}\right)$.

- treatment 6: 100\% of neem cake $\left(42.39 \mathrm{~cm}^{3}\right)$.

After establishing the treatments, they were put in bigger plastic bottles $(100 \mathrm{~mL})$ with perforated lids to allow aeration. Ten larvae were released in each replicate. The experiment was completely randomized and there were 10 replicates for each treatment. During the experiment, daily observations were made on the larval viability, pupal period, pupal mortality and sex ratio of the emerged adults.

\subsection{Data analyses}

A probit regression was performed for the pupal mortality data using SAS 9.1 software [20] to estimate the lethal concentrations ( $\mathrm{LC}_{50}$ and $\mathrm{LC}_{90}$, that are required doses to induce $50 \%$ and $90 \%$ of mortality in the population, respectively).

The variables pupal period, pupal mortality and sex ratio of the $C$. capitata adults were submitted to analysis of variance by the $F$ test $(p<0.05)$, and, when a significant difference was detected, the Tukey test ( $\alpha=0.05$ ) was applied to compare the means. Bartlett [21] and Shapiro-Wilk [22] tests were applied to check for the homoscedasticity assumptions. The analyses were performed by SAS software [20].

\section{Results}

The immobilization and pupation of $C$. capitata larvae were not affected by the neem seed cake. Larvae held the same patterns of development, transforming into pupae in $24 \mathrm{~h}$ after the beginning of the bioassay regardless of the neem cake concentration. One hundred percent of the larvae reached the pupal stage.

At the pupal stage, however, high mortality was observed $(F=211.80$; df $=14.99$; $P<0.0001)$. The pupal mortality induced by the neem cake was dose-dependent (figure 1). In the control (without neem seed cake in the vermiculite), $97 \%$ of the adults emerged. In the treatment with $10 \%$ of neem cake in the vermiculite, 93\% of the adults emerged, demonstrating no significant difference to the control. At the $25 \%$ and above concentrations, significant mortalities were observed. When $50 \%$ of the neem cake was added to the vermiculite, only $17 \%$ of the adults emerged. At $75 \%$ and $100 \%$ concentrations, highly deleterious effects on the medfly pupae were observed. Only three insects emerged at $75 \%$ of the neem cake and none of the flies emerged when only neem cake was used as pupation substrate. Both of these treatments differed significantly from the control and the other treatments (figure 1).

The pupal mortality was shown to be the best variable to represent the effect of the seed cake on $C$. capitata. Part of the effect still remained hidden, because the pupa is protected inside the puparium. No physically unusual symptom was observed on the puparium, such as change in color or deformation.

The probit linear regression for the pupal mortality (figure 2) allowed us to determine that the estimated concentrations to kill 50\% and $90 \%$ of the population ( $\mathrm{LC}_{50}$ and $\mathrm{LC}_{90}$ ) were $30.6 \%(26.7 ; 33.9)$ and 57.2\% (51.6; 65.3) of neem seed cake, respectively.

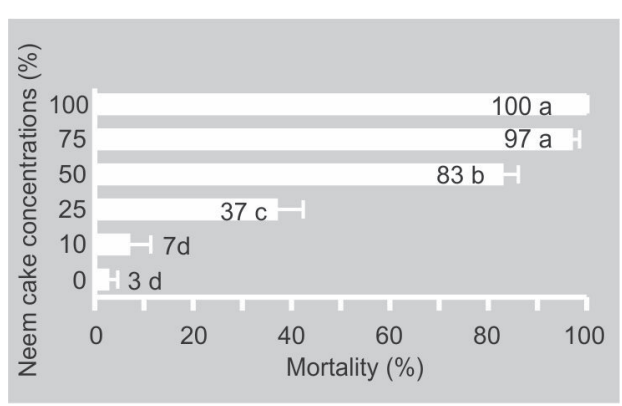

Figure 1.

Mortality of Ceratitis capitata after the exposure of the prepupal stage to different concentrations of neem seed cake in pupation substrate under laboratory conditions ( $n=100$ flies per treatment). Means followed by different letters in the bars differ by Tukey 's test $(p<0.0001)$. 
Figure 2.

Probit linear regression between the neem seed cake concentrations of the pupation substrate and the Ceratitis capitata mortality.

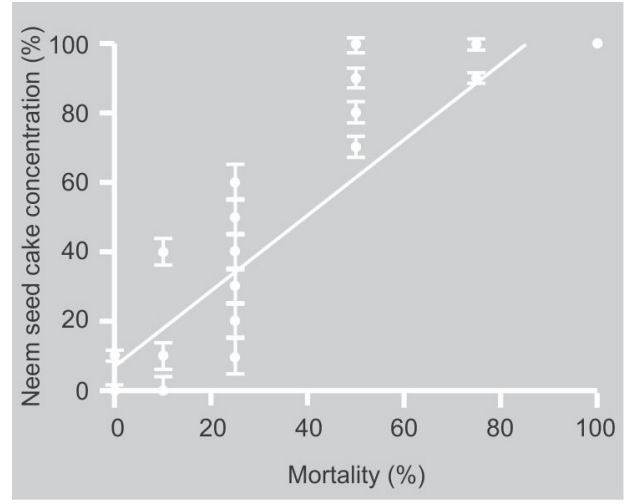

The contact of the immature stages of C. capitata with the neem seed cake also resulted in an increase in the pupal period $(F=4.53 ; \mathrm{df}=3.16 ; P=0.0085)$ (table I). The sex ratio of the emerged adults ranged from 0.33 to 0.48 and significant differences were observed among them $(F=7.03$; $\mathrm{df}=35.30 ; P=0.03$ ), but not with the control (table I).

\section{Discussion}

The immobilization and pupation of $C$. capitata larvae in contact with the treated pupal substrate were not affected. The medfly larval stage was exposed to the neem cake up to $24 \mathrm{~h}$ before the transformation into the pupal stage. The time of exposure was probably not enough to affect the larvae. The processes of immobilization and pupation are induced by the molting hormone (ecdysone) associated with distinct peptide neurohormones in Diptera [23] and as the interference of azadirachtin in the neuroendocrine system of insects is its main action site [24-26], we expected some effect on prepupae. Treatment with azadirachtin may change the levels of ecdysone and other ecdysteroid hormones in the hemolymph, possibly by interfering in the production and release of the prothoracicotropic hormone (PTTH) from the corpora allata, which results in a decrease in its production by the neurosecretory cells of the brain by a feedback effect [25, 27].

In our experiments, we observed a decrease in the developmental rate followed by insect death (table I, figure 1). Our results indicate that the seed cake acts as an insect growth regulator for the medfly. The growth regulator effect is characterized by developmental delays, deformation and mortality [25]. The insects that survive the azadirachtin treatment usually show

\begin{tabular}{|c|c|c|c|}
\hline & & Pupal period & Sex ratio \\
\hline $\begin{array}{l}\text { Vermiculite } \\
(\%)\end{array}$ & $\begin{array}{l}\text { Neem cake } \\
(\%)\end{array}$ & & \\
\hline 100 & 0 (control) & $8.15 \pm 0.06 a$ & $0.48 \pm 0.04 \mathrm{ab}$ \\
\hline 90 & 10 & $8.22 \pm 0.05 \mathrm{ab}$ & $0.50 \pm 0.03 \mathrm{ab}$ \\
\hline 75 & 25 & $8.44 \pm 0.07 \mathrm{ab}$ & $0.54 \pm 0.05 a$ \\
\hline 50 & 50 & $8.53 \pm 0.13 b$ & $0.33 \pm 0.13 b$ \\
\hline 25 & $75^{3}$ & - & - \\
\hline 0 & $100^{3}$ & - & - \\
\hline
\end{tabular}


anomalies that are revealed by deformation on the insect body parts [16]. In our work, few deformed insects emerged. However, Stefeens and Schumutter [11] demonstrated a reduction in the medfly flight ability when larvae were reared on a diet with methanolic extract of neem seeds. The incidence of deformed insects may probably be higher when the immature stages feed on neem compounds.

Among the limonoids, azadirachtin is the main compound responsible for the insect growth regulator effect [25, 28]. Evidence suggests that other limonoids in neem extracts may increase the efficiency of products based on azadirachtin [29]. More than 130 limonoids have already been isolated from different parts of the neem plant [30]. In the seeds, the most abundant limonoid is azadiradione [31]. Salanin is the most common among the most polar limonoids extracted, followed by azadirachtin and, on a smaller scale, 3-tigloylazadirachtol [32]. Azadirachtin and 3-tigloylazadirachtol are the main insecticide metabolites present in the seeds and are probably responsible for immature medfly mortality. In the neem seed, there are also other molecules with chemical structure very similar to azadirachtin, but with variable biological activity [12, 33-35].

Prolonged duration of pupal development as observed in our work is interesting because the insects would be exposed to natural enemies for a longer time period and an asynchrony among the adults would occur. The association between the neem cake and the natural enemies would strengthen the field measures to control the medfly. The azadirachtin did not affect the parasitoids Diachasmimorpha longicaudata (Ashmed) and Diachasmimorpha tryoni (Cameron), when 3rd instar larvae of Bactrocera dorsalis parasitized by D. longicaudata and larvae of $C$. capitata parasitized by D. tryoni were exposed to treated sand [36]. The use of neem seed cake in association with biological control agents may be favored by the fact that azadirachtin is more efficient by ingestion than by contact. Furthermore, the azadirachtin is rapidly eliminated from the insect, which avoids the exposure of natural enemies to the same doses of azadirachtin to which the prey was submitted [16].

\section{Conclusion}

The neem seed cake revealed contact action on the larval-pupal stage of C. capitata. Concentrations in the pupation substrate of over $50 \%$ cause high mortality and induce delay in the pupal period. The immobilization, pupation and sex ratio of the emerged adults are not affected by the neem cake.

\section{Acknowledgments}

The Fundação de Amparo à pesquisa de Minas Gerais (FAPEMIG, Brazil) for financial support to research and the scholarships awarded to the first and second authors (Scientific Initiation and BIPDT, respectively).

We thank Patrícia Cruz and Heliselle Rocha for helping with the insect rearing, and Marcos Lima for comments on an earlier draft.

\section{References}

[1] Malavasi A., Zucchi R.A., Sugayama R.L., Biogeografia, in: Malavasi A., Zucchi R.A. (Eds.), Moscas-das-frutas de importância econômica no Brasil: conhecimento básico e aplicado, Holos, Ribeirão Preto, SP, 2000.

[2] Aluja M., Bionomics and management of Anastrepha, Annu. Rev. Entomol. 39 (1994) 155-178.

[3] Chen C., Dong Y., Cheng L., Hou R.F., Deterrent effect of neem seed kernel extract on oviposition of the oriental fruit fly (Diptera: Tephritidae) in guava, J. Econ. Entomol. 89 (1996) 462-466.

[4] Singh S., Singh R.P., Neem (Azadirachta indica) seed kernel extracts and azadirachtin as oviposition deterrents against the melon fly (Bactrocera cucurbitae) and the oriental fruit fly (Bactrocera dorsalis), Phytoparasitica 26 (1998) 191-197.

[5] Valencia-Botín A.J., Bautista-Martinez N., López-Buenfil J.A., Uso de extractos acuosos de nim, Azadirachta indica A. Juss., en la oviposición de la mosca mexicana de la fruta 
Anastrepha ludens Loew (Diptera: Tephritidae) en naranja Valencia, Fitosanidad 8 (2004) 57-59.

[6] Stark J.D., Vargas R.I., Thalman R.K., Azadirachtin: Effects on metamorphosis, longevity, and reproduction of three tephritid fruit fly species (Diptera: Tephritidae), J. Econ. Entomol. 83 (1990) 2168-2174.

[7] Van Randen E.J., Roitberg B.D., Effect of a neem (Azadirachta indica)-based insecticide on oviposition deterrence, survival, behavior and reproduction of adult western cherry fruit fly (Diptera: Tephritidae), J. Econ. Entomol. 91 (1998) 123-131.

[8] Singh S., Effects of aqueous extract of neem seed kernel and azadirachtin on the fecundity, fertility and post-embryonic development of the melonfly, Bactrocera cucurbitae, and the oriental fruit fly, Bactrocera dorsalis (Diptera: Tephritidae), J. Appl. Entomol. 127 (2003) 540-547.

[9] Di llio V., Cristofaro M., Marchini D., Nobili P., Dallai R., Effects of a neem compound on the fecundity and longevity of Ceratitis capitata (Diptera: Tephritidae), J. Econ. Entomol. 92 (1999) 76-82.

[10] Salles L.A.B., Rech N.L., Efeito de extratos de nim (Azadirachta indica) e cinamomo (Melia azedarach) sobre Anastrepha fraterculus (Wied.) (Diptera: Tephritidae), Rev. Bras. Agrocienc. 5 (1999) 225-227.

[11] Steffens R.J., Schmutterer H., The effects of a crude methanolic neem (Azadirachta indica) seed kernel extract on metamorphosis and quality of adults of the Mediterranean fruit fly, Ceratitis capitata Wied. (Dip: Tephritidae), Z. angew. Ent. 94 (1983) 98-103.

[12] Veitch G.E., Boyer A., Ley S.V., The azadirachtin story, Angew. Chem. Int. Ed. Engl. 47 (2008) 9402-9429.

[13] Veitch G.E., Beckmann E., Burke B.J., Boyer A., Maslen S.L., Ley S.V., Synthesis of azadirachtin: A long but successful journey, Angew. Chem. Int. Ed. Engl. 46 (2007) 76297632.

[14] Ley S.V., Abad-Somovilla A., Anderson J.C., Ayats C., Bonteli R., Beckmann E., Boyer A., Brasca M.G., Brice A., Broughton H.B., Burke B.J., Cleator E., Craig D., Denholm A.A., Denton R.M., Durand-Reville T., Gobbi L.B., Gobel M., Gray B.L., Grossmann R.B., Gutteridge C.E., Hahn N., Harding S.L., Jennens D.C., Jennens L., Lovell P.J., Lovell H.J., Puente M.L., Kolb H.C., Koot W., Maslen S.L., Mccusker C.F., Mattes A., Pape A.R., Pinto A., Santafianos D., Scott J.S.,
Smith S.C., Somers A.Q., Spilling C.D., Stelzer F., Toogood P.L., Turner R.M., Veitch G.E., Wood A., Zumbrunn C., The synthesis of Azadirachtin: a potent insect antifeedant, Chem. Eur. J. 14 (2008) 10683-10704.

[15] Ermel K., Azadirachtin content of neem seed kernels from different regions of the world, in: Schmutterer H. (Ed.), The neem tree, source of unique natural products for integrated pest management, medicine, industry and other purposes, VCH, Weinh., Ger., 1995.

[16] Martinez S.S., O nim - Azadirachta indica: natureza, usos múltiplos, produção, IAPAR, Londrina, Brazil, 2002.

[17] Carneiro S.M.T.P.G., Ação do nim sobre fungos fitopatogênicos, in: Martinez S.S. (Ed.), O nim - Azadirachta indica: natureza, usos múltiplos, produção, IAPAR, Londrina, Brazil, 2002.

[18] Akhtar M., Nematicidal potential of the neem tree (Azadirachta indica A. Juss.), Integr. Pest Manag. Rev. 5 (2000) 57-66.

[19] Carvalho R.S., Nascimento A.S, Criação e utilização de Diachasmimorpha longicaudata para controle biológico de moscasdas-frutas (Tephritidae), in: Parra J.R.P., Botelho P.S.M., Corrêa-Ferreira B.S., Bento J.M.S. (Eds.), Controle biológico no Brasil: parasitóides e predadores, Manole, São Paulo, Brazil, 2002.

[20] Anon., Statistical Analysis System, version 9.1., SAS Inst., Cary, NC, U.S.A., 2003.

[21] Bartlett M.S., Properties of sufficiency and statistical tests, Proc. R. Soc. Lond. A. 160 (1937) 268-282.

[22] Shapiro S.S., Wilk M.B., An analysis of variance test for normality, Biometrika 52 (1965) 591-611.

[23] Gilbert L.I., The endocrine control of molting: the tobacco hornworm, Manduca sexta, as a model system, in: Koolman J. (Ed.), Ecdysone, Georg Thieme Verlag, Stuttg., Ger., 1989.

[24] Schumutterer H., Properties and potential of natural pesticides from the neem tree, Azadirachta indica, Annu. Rev. Entomol. 35 (1990) 271-297.

[25] Mordue (Luntz) A.J., Blackwell A., Azadirachtin: An update, J. Insect Physiol. 39 (1993) 903-924.

[26] Mordue (Luntz) A.J., Morgan E.D., Nisbet A.J., Azadirachtin, a natural product in insect control, in: Gilbert L.I., latrou K., Gill S.S. (Eds.), Comprehensive molecular insect science, Elsevier, Amst., Neth., 2005. 
[27] Rembold H., Biological effects of neem and their modes of action: growth and metamorphosis, in: Schmutterer H. (Ed.), The neem tree: source of unique natural products for integrated pest management, medicine, industry and other purposes, $\mathrm{VCH}$, Weinh., Ger., 1995.

[28] Mordue (Luntz) A.J., Nisbet A.J., Azadirachtin from the neem tree Azadirachta indica: its action against insects, An. Soc. Entomol. Bras. 29 (2000) 615-632.

[29] Stark J.D., Walter J.F., Neem oil and neem oil components affect the efficacy of commercial neem insecticides, J. Agric. Food Chem. 43 (1995) 507-512.

[30] Kanokmedhakul S., Kanikmedhakul K., Prajuabsuk T., Panichajakul S., Panyamee P., Prabpai S., Kongsaeree, P., Azadirachtin derivatives from seed kernels of Azadirachta excelsa, J. Nat. Prod. 68 (2005) 1047-1050.

[31] Lavie D., Jain M.K., Tetranortriterpenoids from Melia azadirachta L., Chem. Commun. 6 (1967) 278-280.
[32] Johnson S., Morgan E.D., Peiris C.N., Development of the major triterpenoids and oil in the fruit and seeds of neem (Azadirachta indica), Ann. Bot. 78 (1996) 383-388.

[33] Rembold H., Azadirachtins, their structure and mode of action. in: Arnasan J.T., Philogène B.J.R., Morand P. (Eds.), Insecticides of plant origin, ACS Symp. Series, 387, Wash., U.S.A., 1989, pp. 1-10.

[34] Ley S.V., Denholm A.A., Wood A., The chemistry of azadirachtin, Nat. Prod. Rep. 10 (1993) 109-157.

[35] Morgan E.D., Azadirachtin, a scientific gold mine, Bioorg. Med. Chem. 17 (2009) 40964105.

[36] Stark J.D., Wong T.T.Y., Vargas R.I., Thalman R.K., Survival, longevity, and reproduction of tephritid fruit fly parasitoids (Hymenoptera: Braconidae) reared from fruit flies exposed to azadirachtin, J. Econ. Entomol. 85 (1992) 1125-1129.

\section{Efecto tóxico de la torta de semilla de neem en el estado prepupa de la mosca de la fruta (Diptera: Tephritidae).}

Resumen - Introducción. Tradicionalmente, la lucha de la mosca de la fruta se basa en el uso de pesticidas, lo que aumenta los costes de producción y acarrea numerosos problemas medioambientales. Nuestro estudio se centró en evaluar el efecto de la torta de neem en los estados larvarios y ninfales de Ceratitis capitata. Material y métodos. Se introdujeron larvas del tercer estado en un frasco de plástico que contenía vermiculita mezclada con torta de semillas de neem en diferentes concentraciones: el tratamiento testigo se constituyó únicamente de vermiculita; otros cinco tratamientos se aplicaron a partir de un $(10,25,50,75$ ó 100) \% de torta de semillas de neem, añadido a la vermiculita. Un bio-ensayo se llevó a cabo, según un dispositivo totalmente aleatorio, con seis tratamientos, diez repeticiones y diez larvas por repetición. Los resultados se analizaron estadísticamente. Resultados. En los medios que contenían vermiculita al $75 \%$ o más de torta de neem, prácticamente ninguna mosca adulta emergió. En los medios al 50 \%, más del $80 \%$ de los adultos no emergieron y, en cuanto a los que emergieron, el periodo ninfal se prolongó. La sex-ratio de los adultos no se vio afectada después del contacto de las crisálidas con la torta de neem. Las concentraciones mortales de torta en el sustrato de pupación, estimadas para matar al $50 \%$ y al $90 \%$ de la población de moscas, fueron respectivamente del 30,6 \% y 51,6\%. Conclusión. La torta de semillas de neem actúa por contacto en el estado prepupa de C. capitata. Esta torta mezclada al sustrato de ninfosis puede provocar una mortalidad elevada, a partir de una concentración del $50 \%$, alarga el periodo larvario de C. capitata.

Brasil / Azadirachta indica / Ceratitis capitata / Tephritidae / control de insectos / plaguicidas de origen vegetal / control biológico 